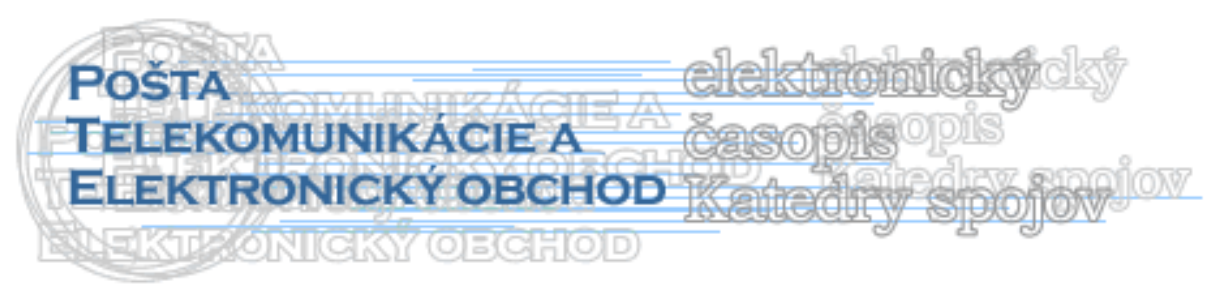

\title{
KÓDOVANIE OZNAČOVANIA ZÁSIELOK NA FYZICKEJ ÚROVNI NOSIČA INFORMÁCIE
}

\author{
Ondrej Maslák*, Juraj Vaculík*
}

\begin{abstract}
The article briefly deal with the Electronic Product Code, and the possibility of its use for labeling of shipments for postal operators.
\end{abstract}

Keywords: RFID, tag, EPC

\section{1. Úvod do problematiky: elektronický produktový kód (EPC)}

EPC je elektronický produktový kód. Tento kód jednoznačne a univerzálne označuje tovar alebo akýkol'vek objekt. Bol vytvorený v centre MIT Auto-Id. Z pomenovania vyplýva, že ide o elektronickú formu identifikácie. Č́slo je zakódované a uložené na nosič napríklad na štítok. Pomocou tohto unikátneho kódu je možné označit' každú jednu vec, výrobok individuálne a jedinečne. Udel'ovanie jednotlivých čísiel má na starosti EPC global, ktorý spadá pod neziskovú organizáciu GS1. Bez autorizácie tejto organizácie nie je možné dostat' a využívat' EPC kód.

Týmto sa zabezpečí unikátnost' a bez kolíznost' pridel'ovaných čísiel . Číslo samo o sebe nemá žiadny konkrétny význam, pokial' nie je prepojene s databázou. EPC ako unikátny kl'úč dovolí pristupovat' k údajom o konkrétnom výrobku, ktoré sú uložené $\mathrm{v}$ databázach.

Zloženie EPC.

- Hlavička- určuje nám typ EPC kódu pre každé z typov identifikačných označení je iná 8bitová kombinácia.

- EPC Manager číslo- prefix firmy a pridelené číslo od GS1- GS1 prefix firmy.

- Druh výrobku- druh výrobku ako skupina nejedná sa o konkrétne označenie výrobku.

- Sériové číslo- toto číslo označuje každý jeden výrobok samostatne nie len druh, môžu sa tu nachádzat' dodatkové informácie o výrobku.[1]

Príklad 96 bitovej verzie EPC kódu

\footnotetext{
${ }^{1}$ Ing. Ondrej Maslák., Žilinská univerzita v Žiline, Fakulta Prevádzky a ekonomiky dopravy a spojov, Katedra spojov, Univerzitná 1, 01026 Žilina, e-mail: ondrej.maslak@fpedas.uniza.sk

${ }^{2}$ prof. Ing. Juraj Vaculík, PhD., Žilinská univerzita v Žiline, Fakulta Prevádzky a ekonomiky dopravy a spojov, Katedra spojov, Univerzitná 1, 01026 Žilina, e-mail: juraj.vaculik@fpedas.uniza.sk
} 




Obr 1. EPC kód (Zdroj: EPC [online]. 2012. [Cit. 2012-01-03]. Dostupné na internete:

< http://www.gs1sk.org/elektronicky-produktovy-kod>)

Príklad vzt’ahu medzi EAN-13 a EPC. Z obrázku je jasné prečo EAN nedokáže niest' informácie o každom jednom výrobku. Neobsahuje sériové číslo.

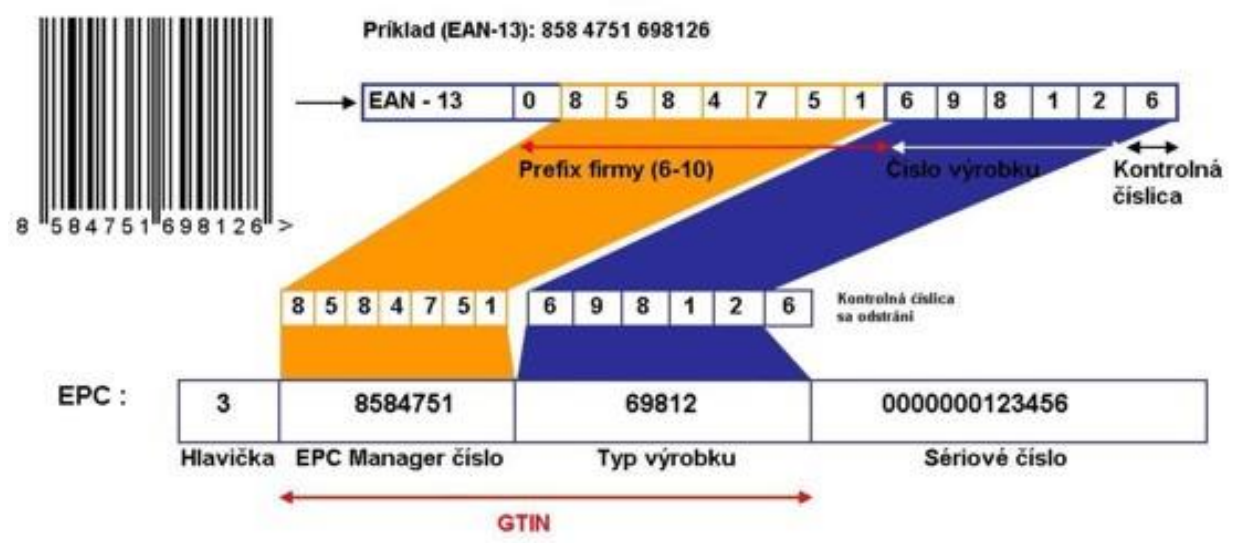

Obr 2. Príklad včlenenia GTIN do EPC (Zdroj:EPC [online]. 2012. [Cit. 2012-01-03]. Dostupné na internete: <http://www.gs1sk.org/elktronicky-produktovy-kod >)

GS1 prefix je pridel'ovaný organizáciou GS1 a označuje organizácia, ktorá ho pridelia. Prefix firmy nasleduje za GS1 prefixom, ktoré je opät' pridelené organizáciou GS1. Spolu GS1 prefix a prefix firmy tvoria GS1 prefix firmy.(Prefix- predpona pred číslie, predvol'ba).

EPC štandardy:

- EPC Tag Data Standard (Štandard pre dáta na štítku),

- EPC Tag Data Translation Standard (Preklad dát na štítku),

- Class 1 Generation 2 UHF Air Interface Protocol Standard: "Gen 2" (Vzdušné rozhranie Trieda 1 Generácia 2 UHF: „Gen2“),

- Low Level Reader Protocol (LLRP) (Protokol pre snímač nízkej úrovne),

- Discovery, Configuration and Inicialisation (Vyhl'adávanie, konfigurácia a inicializácia),

- Reader Management (Správa snímača),

- Application Level Events (ALE) (Udalosti na úrovni aplikácie),

- Electronic Product Code Information Services (EPCIS) (Informačné služby),

- Core Business Vocabulary (Základný slovník),

- Object Naming Service (ONS) (Služba pomenovania objektov),

- Certificate Profile (Certifikacný profil),

- Pedigree Standard (Štandard pre pôvod),

- EPCglobal Architecture Framework (Architektúra EPCglobal). [2] 
Vybrané typy identifikačných čísiel v GS1:

- GTIN - Globálne identifikačné číslo,

- GLN - Globálne lokačné číslo,

- GSRN - Globálne identifikačné číslo služby,

- SSCC - Identifikačné číslo prepravnej jednotky,

- GIAI - Globálny individuálny identifikátor pre majetok,

- GRAI - Globálne identifikačné číslo pre vratný majetok,

- GDTI - Globálne identifikačné číslo typu dokumentu. [3]

\section{2. Štandard EPC tag data}

Dáta uložené v RFID štítku majú predpísanú formu, ktorá je definovaná v EPC Tag data štandarde verzia 1.8 (najnovšia verzia február 2014 k dispozícií vol'ne na stiahnutie http://www.gs1.org/gsmp/kc/epcglobal/tds/). V tomto konkrétnom prípade sa jedná o predpísanú formu dát elektronického produktového kódu zapisovaného na RFID štítky druhej generácie. RFID štítky sú schopné obsiahnut' rôzne druhy obsahu s rôznym formátovaním. Tento štandard definuje dve hlavné oblasti:

- Špecifikáciu EPC kódu a jeho reprezentácia na rôznych úrovniach, architektúru a vzt’ah medzi EPC kódom a GS1 klúčmi.

- Samotnú špecifikáciu dát, ktorá je uložená na fyzickom RFID štítku.

Elektronický produktový kód je kód, ktorý existuje v rôznych formách a môže byt' uložený v rôznych tvaroch. Nie je nevyhnutné, aby bol EPC kód vždy uložený len na RFID štítku. EPC kód je kód, s ktorým pracujú systémy, databázy a existuje oddelene od RFID štítku, ktorý je len jeden z možných nosičov pre tento kód. [4]

Základné formy EPC kódu sú:

- EPC ktorý je presne v tvare GS1 klúča,

- EPC „Pure Identity“ Čistá identita,

- EPC TAG URI (len v prostredí RFID),

- EPC Raw URI (zvyčajne v prípade že štítok neobsahuje platný EPC kód),

- EPC binárna forma (len v prostredí RFID). [5]

EPC, ktorý je uložený do RFID štítku je uložený v takzvanej EPC binárnej forme, aby sa predišlo zbytočnému zahlcovaniu kapacity štítku. EPC kód používaný $\mathrm{v}$ rámci počítačových sietí a databáz je reprezentovaní formou URI (Internet Uniform Resource Identifier). Príklad Pure Identity EPC URI: urn:epc:id:sgtin:0614141.112345.400. Nezáleží na nosiči, z ktorého bol EPC prečítaný.

GIAI- Global Individual asset identifier (Identifikátor označujúci všetok majetok vrátane vratného majetku). Všeobecný predpis EPC URI pre GIAI je urn:epc:id:giai:PrefixFirmy. IndividuálneČísloMajetku. SGLN- Identifikátor pre označenie miesta ako napríklad budovy, skladu, poličky a podobne. Všeobecný zápis je v tvare: urn:epc:id:sgln:PrefixFirmy.Lokácia.Rozšírenie. Lokácia obsahuje špeciálnu identifikáciu odkazujúcu na fyzickú lokáciu.[4]

\section{EPC binárna forma (EPC binary encoding)}

Jedna z možných foriem EPC kódu, ktorá sa výlučne používa $\mathrm{v}$ koncepte RFID technológie. Jedná sa o najnižšiu formu záznamu EPC kódu v podobe retazca bitov uloženého do RFID štítku. Ret’azec začína hlavičkou s definovanou dížkou a následnými údajmi. V hlavičke je zadefinované o aké údaje sa jedná, aké majú vel'kost' a funkciu. 
Podl'a hodnoty hlavičky sa následne vyberá zodpovedajúca kódovacia tabul'ka. Hlavička má vel'kost' jeden bajt, čiže 8 bitov. Následne máme k dispozícií 255 možných hlavičiek s možnost'ou rezervovanej v tvare 1111 1111. Táto hlavička je určená pre budúce použitie a hovorí, že hlavička je dlhšia ako 8 bitov a teda sú možné d’alšie kombinácie. [4]

Vybrané príklady hlavičiek a ich význam:

Tabul'ka 1. Vybrané typy hlavičiek a ich význam

\begin{tabular}{|c|c|c|c|}
\hline Binárna reprezentácia & Hexdecimálny tvar & Vel'kost' v bitoch & názov \\
\hline 11111111 & FF & Nedefinovaná & $\begin{array}{c}\text { Rezervovaná pre } \\
\text { hlavičky väčšie ako 8 bit }\end{array}$ \\
\hline 00110011 & 33 & 96 & GRAI-96 \\
\hline 00110010 & 32 & 96 & SGLN-96 \\
\hline 00110100 & 34 & 96 & GIAI-96 \\
\hline 00110110 & 36 & 198 & GGTIN-198 \\
\hline 00110111 & 37 & 170 & GIAI-202 \\
\hline 00111000 & 38 & 202 & SGLN-195 \\
\hline 00111001 & 39 & 195 & 95 \\
\hline
\end{tabular}

Zdroj: GS1 EPC Tag Data Standard 1.6. 2011. [online]. [Cit. 2012-20-03]. Dostupné na internete:

<http://www.gs1.org/gsmp/kc/epcglobal/tds/tds_1_6-RatifiedStd-20110922.pdf〉.

\section{Kódovacie tabul'ky pre SGLN}

SGLN slúži na označenie miestností, v ktorých sa majetok nachádza. Pomocou týchto kódovacích tabuliek môžeme previest' EPC Tag URI do binárnej formy. Z tabuliek zistíme aké kódovacie metódy na jednotlivé časti kódu sú použité a takisto ich vel'kost' a poradie bitov. Zo zápisom EPC do banky štítku sa začína na 20h bite banky 01 a okrem biznis informácie akou je EPC, sa nachádza v tejto sekcií aj kontrolná informácia a to hodnota filtra. EPC s filtrom nemá obdobu v GS1 kl'úči. Filter ako trojbitová hodnota slúži len na ul'ahčenie práce s čítaním štítkov a nie je posielaný do vyšších úrovní EPC kódu spracovávanom v databázach a informačných systémoch. [4]

SGLN: Hodnota oddielu alebo partície je jednoduchá informácia pomocou, ktorej vieme kde nám končí GS1 Prefix firmy a kde začína odkaz na pozíciu. V tabul'ke nižšie vidíme jednotlivé kombinácie 3 bitovej hodnoty partície a ako ovplyvní pomer čísiel prefixu a odkazu na pozíciu. [4]

Tabul'ka 2. SGLN význam oddielu

\begin{tabular}{|c|c|c|c|c|}
\hline \multirow{2}{*}{$\begin{array}{l}\text { Hodnota oddielu } \\
\text { Patrition Value (P) }\end{array}$} & \multicolumn{2}{|c|}{ GS1 Prefix firmy } & \multicolumn{2}{|c|}{ Odkaz na pozíciu (Local Reference) } \\
\hline & Bity (M) & Č́́slice (L) & $\operatorname{Bity}(N)$ & Č́slice \\
\hline $\mathbf{0}$ & 40 & 12 & 1 & $\mathbf{0}$ \\
\hline 1 & 37 & 11 & 4 & 1 \\
\hline 2 & 34 & 10 & 7 & 2 \\
\hline 3 & 30 & 9 & 11 & 3 \\
\hline 4 & 27 & 8 & 14 & 4 \\
\hline 5 & 24 & 7 & 17 & 5 \\
\hline 6 & 20 & 6 & 21 & 6 \\
\hline
\end{tabular}

Zdroj: GS1 EPC Tag Data Standard 1.6. 2011. [online]. [Cit. 2012-02-04]. Dostupné na internete:

<http://www.gs1.org/gsmp/kc/epcglobal/tds/tds_1_6-RatifiedStd-20110922.pdf>. 


\section{Príklad fyzického kódovania pre vybraný identifikátor}

SGTIN- Serialized Global Trade Item Number- Serializované globálne identifikačné číslo obchodnej jednotky.

Tabul'ka 3. SGTIN význam oddielu/partície

\begin{tabular}{|c|c|c|c|c|}
\hline $\begin{array}{c}\text { Hodnota oddielu } \\
\text { Patrition Value (P) }\end{array}$ & \multicolumn{2}{|c|}{ GS1 Prefix firmy } & \multicolumn{2}{c|}{ Indikačná ćśsica a odkaz na tovar } \\
\hline & Bity (M) & Číslice (L) & Bity(N) & Ć́slice \\
\hline 0 & 40 & 12 & 1 & 0 \\
\hline 1 & 37 & 11 & 4 & 2 \\
\hline 2 & 34 & 10 & 11 & 3 \\
\hline 3 & 30 & 9 & 14 & 4 \\
\hline 4 & 27 & 8 & 17 & 6 \\
\hline 5 & 24 & 7 & 21 & 5 \\
\hline 6 & 20 & 6 & 7 & 6 \\
\hline
\end{tabular}

Zdroj: GS1 EPC Tag Data Standard 1.6. 2011. [online]. [Cit. 2012-02-04]. Dostupné na internete:

<http://www.gs1.org/gsmp/kc/epcglobal/tds/tds_1_6-RatifiedStd-20110922.pdf>.

Tabul'ka 4. Kódovacia tabul'ka SGTIN-96 bitová verzia

\begin{tabular}{|c|c|c|c|c|c|c|}
\hline Schéma & \multicolumn{6}{|c|}{ SGTIN-96 } \\
\hline URI šablóna & \multicolumn{6}{|c|}{ urn:epc:tag:sgtin-96:F.C.I.S } \\
\hline $\begin{array}{c}\text { Celková } \\
\text { vel'kost' v } \\
\text { bitoch }\end{array}$ & \multicolumn{6}{|c|}{96} \\
\hline $\begin{array}{l}\text { Logická } \\
\text { schéma }\end{array}$ & EPC Hlavička & Filter & Patrícia & $\begin{array}{l}\text { GS1 Prefix } \\
\text { firmy }\end{array}$ & $\begin{array}{c}\text { Odkaz na } \\
\text { tovar }\end{array}$ & Sériové číslo \\
\hline $\begin{array}{c}\text { Vel'kost' } \\
\text { segmentov v } \\
\text { bitoch }\end{array}$ & 8 & 3 & 3 & $20-40$ & $24-4$ & 38 \\
\hline $\begin{array}{l}\text { Kódovací } \\
\text { segment }\end{array}$ & EPC hlavička & Filter & \multicolumn{3}{|c|}{ SGTIN } & Sériové číslo \\
\hline URI čast' & & $\mathbf{F}$ & \multicolumn{3}{|c|}{ C.I } & $\mathbf{S}$ \\
\hline $\begin{array}{c}\text { Počet bitov } \\
\text { kódovaného } \\
\text { segmentu }\end{array}$ & 8 & 3 & \multicolumn{3}{|c|}{47} & 38 \\
\hline Pozícia bitov & $\mathbf{b}_{95} \mathbf{b}_{94} \ldots \mathbf{b}_{88}$ & $\mathbf{b}_{87} \mathbf{b}_{86} \mathbf{b}_{85}$ & \multicolumn{3}{|c|}{$\mathbf{b}_{84} \mathbf{b}_{83} \ldots \mathbf{b}_{38}$} & $\mathbf{b}_{37} \mathbf{b}_{36} \ldots \mathbf{b}_{0}$ \\
\hline $\begin{array}{l}\text { Kódovacia } \\
\text { metóda }\end{array}$ & 00110000 & Integer & \multicolumn{3}{|c|}{ Tabul'ka hore } & Integer \\
\hline
\end{tabular}

Zdroj: GS1 EPC Tag Data Standard 1.6. 2011. [online]. [Cit. 2012-02-04]. Dostupné na internete: <http://www.gs1.org/gsmp/kc/epcglobal/tds/tds_1_6-RatifiedStd-20110922.pdf〉.

Vstupné údaje:

- Prefix firmy- company prefix, prefix firmy: 123456789

- odkaz na jednotku: 1011

- sériové číslo: 123456789987 
Hexadecimálny tvar prečítaný ručnou čítačkou zo štítka: 300C75BCD150FCDCBE991DE3

Hexadecimálny tvar prevedený na binárny tvar:

001100000000110001110101101111001101000101010000111111001101110010111110100 110010001110111100011

Rozložený binárny tvar podl'a kódovacej tabul'ky pre SGTIN 96 bit:

00110000 -hlavička SGTIN 96 bitová verzia

000-filter (all others)

011 - partícia (011 je integer číslo 3)-Tabul'ka SGTIN význam oddielu/partície hore vyznačené žltým.

Na tomto (15tom bite) začína prefix firmy, company prefix a bude mat' dížku 30 bitov: 000111010110111100110100010101 - tu konči prefix firmy- company prefix (kódovacia metóda integer čísla, 123456789)

\begin{tabular}{|l|c|}
\hline Binárny tvar & 000111010110111100110100010101 \\
\hline Desiatkový tvar & 123456789 \\
\hline 16-tkový tvar & $75 \mathrm{BCD} 15$ \\
\hline
\end{tabular}

Na tomto bite začína odkaz na obchodnú jednotku (item reference), podl'a particie je jeho dížka 14 bitov

00001111110011 - Na tomto mieste končí odkaz na obchodnú jednotku (integer číslo 1011)

\begin{tabular}{|l|c|}
\hline Binárny tvar & $\mathbf{0 0 0 0 1 1 1 1 1 1 0 0 1 1}$ \\
\hline Desiatkový tvar & 1011 \\
\hline 16-tkový tvar & $3 \mathrm{~F} 3$ \\
\hline
\end{tabular}

Na tomto mieste začína sériové číslo 01110010111110100110010001110111100011 tu končí sériové číslo (kódovacia metóda integer, čísla 123456789987)

\begin{tabular}{|l|c|}
\hline Binárny tvar & 01110010111110100110010001110111100011 \\
\hline Desiatkový tvar & 123456789987 \\
\hline 16-tkový tvar & 1CBE991DE3 \\
\hline
\end{tabular}

Sériové číslo je vždy posledných 38 bitov pri tej 96 bitovej verzii SGTIN-96 bitového EPC kód podl'a GS1 company.

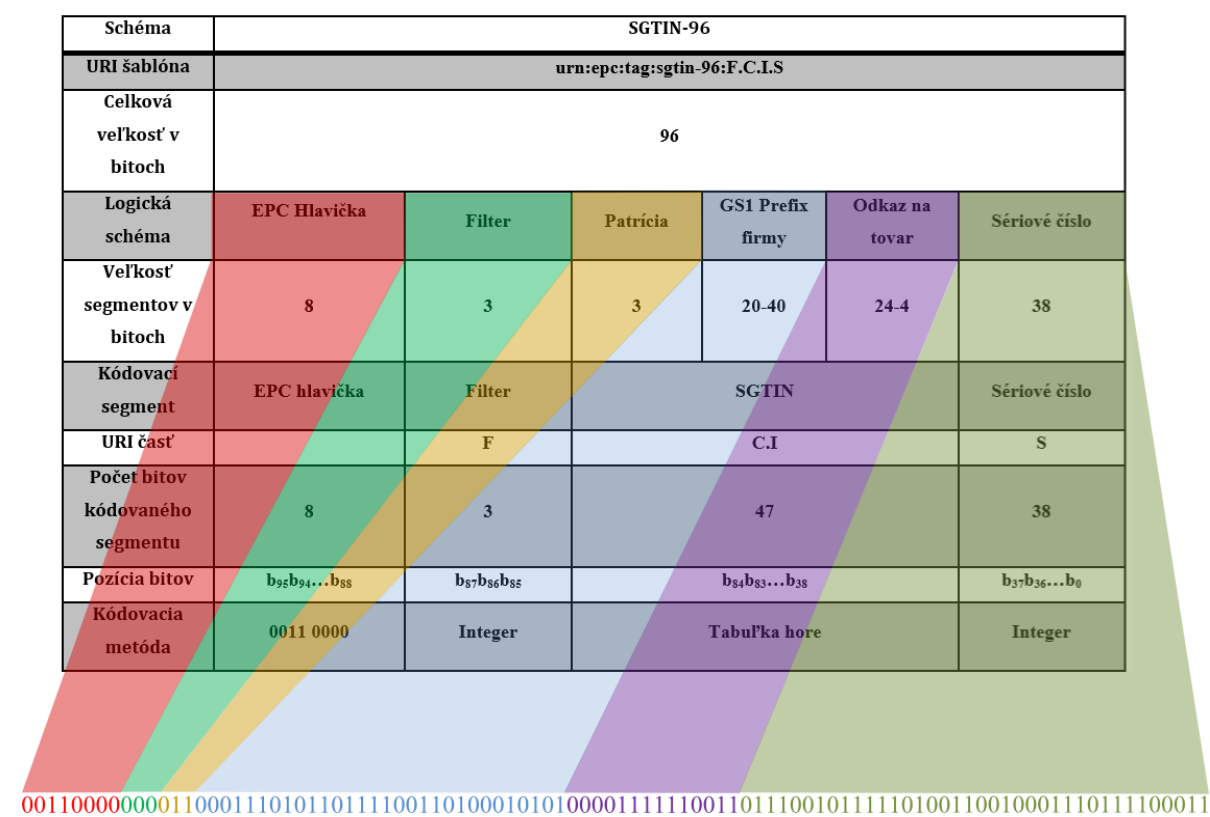

Obr 3. Príklad SGTIN-96. Zdroj: Vlastné spracovanie. GS1 EPC Tag Data Standard 1.6. 2011. [online]. [Cit. 201202-04]. Dostupné na internete: <http://www.gs1.org/gsmp/kc/epcglobal/tds/tds_1_6-RatifiedStd-20110922.pdf>. 


\section{Využitie výhody v maloobchode a vel'koobchode.}

Výhodou označovania pomocou elektronického produktového kódu je jednotná databáza a unikátnost' jednotlivých identifikačných čísiel v rámci systému a medzinárodná štandardizácia. Za unikátnost' zodpovedajú spoločnost' GS1, ktorá pridel'uje company prefix a samotná firma, ktorá zodpovedá za zvyšnú čast' kódu. Toto riešenie je vhodné pre distribučno- riadiace ret'azce, v rámci ktorých je možné kontrolovat' obchodné jednotky, prepravné jednotky, vratný majetok a zefektívnit' riadenie zásob a podobne.

Výhody a nevýhody použitia systému EPC pre poštových operátorov: Elektronický produktový kód je fungujúci koncept s vnútorným prostredím a infraštruktúrou. Organizácia GS1, ale v súčasnosti nedisponuje hlavičkou pre poštové podniky. Z tabul'ky 1. hore vyplýva, že možných kombinácií pre hlavičku je 255 a v súčasnosti je dostatok vol'ných alebo rezervovaných pozícií. Z technického hl'adiska je dostatok vol'ných pozícií pre nové hlavičku.

K získaniu certifikácie a následnému zavedeniu štandardu pre poštových operátorov by muselo dôjst' k zhode a návrhu riešenia od koncových zákazníkov (poštových podnikov) a dopytu pre toto riešenie, čo nie je jednoduchý proces. Následne by musela GS1 toto riešenie zaviest' do svojich štandardov.

\section{Možné kódovania označenia zásielky na fyzickej úrovni}

Modelový prípad štandardizovaného kódovanie fyzickej štruktúry na binárnej úrovni: Pri štandardnej vel'kosti EPC pamäte RFID štítku 96 bitov by sme analogicky museli rezervovat' 8 bitov pre hlavičku 3 bity pre filter 3 bity pre partíciu a najmenej 20-24 bitov určených pre company prefix, ktorý pridelí organizácia GS1 poštovým operátorom. Ďalej by bolo možné vyhradit' 6-10 bitov pre možnú d'alšiu identifikáciu. Na rozlíšenie premenlivého pomeru bitov vyhradených pre GS1 prefix firmy a identifikáciou by slúžila práve hodnota partície (kódovacia metóda integer, tabul'ka 5 dole).

Týmto by sme dosiahli štandardizáciu na medzinárodnej úrovni, ale za cenu zavedenia štandardizačných a riadiacich informácií do EPC pamäte štítka (v modelovom prípade 44 bitov). Modelová kódovacia tabul'ka pre možný EPC pre poštové podniky by mohla vyzerat' nasledovne:

Tabul'ka 5. Modelový príklad binárnej kódovacej tabul'ky pre POST-96 identifikátor.

\begin{tabular}{|c|c|c|c|c|c|c|}
\hline Schéma & \multicolumn{6}{|c|}{ POST-96 } \\
\hline Celková & \multicolumn{6}{|c|}{96} \\
\hline URI šablóna & \multicolumn{6}{|c|}{ urn:epc:tag:post-96:F.P.I.S } \\
\hline Logická schéma & EPC Hlavička & Filter & Patrícia & GS1 Prefix firmy & Identifikácia & Sériové číslo \\
\hline $\begin{array}{c}\text { Vel'kost' } \\
\text { segmentov v } \\
\text { bitoch }\end{array}$ & 8 & 3 & 3 & $20-24$ & $10-6$ & 52 \\
\hline $\begin{array}{c}\text { Kódovací } \\
\text { segment }\end{array}$ & EPC hlavička & Filter & \multicolumn{3}{|c|}{ POST } & Sériové číslo \\
\hline $\begin{array}{c}\text { Počet bitov } \\
\text { kódovaného } \\
\text { segmentu }\end{array}$ & 8 & 3 & \multicolumn{3}{|c|}{30} & 52 \\
\hline URI čast' & & $\mathbf{F}$ & \multicolumn{3}{|c|}{ P.I } & $\mathbf{S}$ \\
\hline Pozícia bitov & b95b94...b88 & b87b86b85 & \multicolumn{3}{|c|}{$b_{84} b_{83} \ldots b_{52}$} & $\mathbf{B}_{51} \mathbf{b}_{50} \ldots \mathbf{b}_{0}$ \\
\hline $\begin{array}{c}\text { Kódovacia } \\
\text { metóda }\end{array}$ & Pridelená hodnota & Integer & \multicolumn{3}{|c|}{ Integer } & Integer \\
\hline
\end{tabular}

Zdroj: Vlastné spracovanie 
Interné kódovanie: Ďalšou možnost'ou ako zaviest' automatickú identifikáciu je použite vlastného systému kódovania informácie na fyzickej úrovni do RFID štítku. Pri použití tohto kódovania odpadá problém s certifikáciou riešenia u certifikačnej autority. zložitý.

Nemusí dôjst' $\mathrm{k}$ dohode medzi ostatnými podnikmi a návrh vlastného systému nie je

Nevýhodou je, že celý systém je interný a nekompatibilný medzi ostatnými účastníkmi. Pri použití rovnakého nosiča o kapacite EPC banky 96bitov budeme mat' $\mathrm{k}$ dispozícií celú vel'kost' pre navrhnutie nášho riešenia. $\mathrm{V}$ podstate sa nevyhneme zavedeniu riadiacich informácií v obdobe partície alebo filtrov. Zakódovat' môžeme okrem sériového čísla, ktoré použijeme ako odkaz na databázu, aj iné informácie, ktoré by mohli napomôct' pri spracovaní balíka, ale neohrozili súkromné informácie (krehké, hmotnost’ a podobne).

\section{Literatúra}

[1] EPC [online]. [Cit. 2012-01-09]. Dostupné na internete: http://www.gs1sk.org/elktronicky-produktovy-kod

[2] Definícia EPC štandardov.[online]. [Cit. 2012-01-05]. Dostupné na internete: <http://www.gs1sk.org/down/prehlad_standardov.pdf>.

[3] ORGANIZÁCIA GS1.: Manuál pre uživatel'ov systému GS1, Patria Prievidza s.r.o, 2010. ISBN 80-967241-3-4

[4] GS1 EPC Tag Data Standard 1.6. 2011. [online]. 2011. [Cit. 2012-02-03]. Dostupné na internete:

<http://www.gs1.org/gsmp/kc/epcglobal/tds/tds_1_6-RatifiedStd20110922.pdf>.

[5] General Questions about the Electronic Product Code (EPC). [online]. [Cit. 2012-0106]. Dostupné na internete: $<$ http://www.kentraub.net/tools/tagxlate/FAQ.html>.

[6] Lahiri, S.: RFID Sourcebook, IBM Press, New York, 2005. ISBN 0131851373.

\section{Grantová podpora}

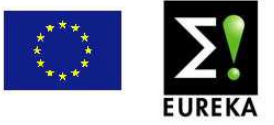

E!7592 AUTOEPCIS - RFID Technology in Logistic Networks of

Automotive Industry (RFID technológie v logistických siet'ach

automobilového priemyslu)

Za podpory Ministerstva školstva, vedy, výskumu a športu. 